\title{
Cladocera (Crustacea, Branchiopoda) of a temporary shallow pond in the Caatinga of Pernambuco, Brazil
}

Leidiane Pereira Diniz, Lourdes Maria Abdu Elmoor-Loureiro, Viviane Lúcia dos Santos Almeida and Mauro de Melo Júnior

(LPD, MMJ) Universidade Federal Rural de Pernambuco - UFRPE, Unidade Acadêmica de Serra Talhada, Laboratório de Ecologia do Plâncton, Fazenda Saco, s/n, 56903-070, Serra Talhada, Pernambuco, Brasil. E-mails: (LPD) leidiane.diniz@hotmail.com; (MMJ) mmelojunior@gmail.com (LMAE-L) Universidade Católica de Brasília - UCB, Laboratório de Zoologia, QS 07, Lote 01, Bloco M, sala 331, 71966-700, Taguatinga, Distrito Federal, Brasil. E-mail: lourdes@ucb.br

(VLSA) Universidade de Pernambuco - UPE, Campus Mata Norte. Rua Amaro Maltez, 201, Centro, 55800-000, Nazaré da Mata, Pernambuco, Brasil. E-mail: vls.almeida@yahoo.com.br

\begin{abstract}
The aim of this study was to describe the composition and structure of cladocerans of littoral areas with and without macrophytes from a temporary shallow pond in the Caatinga of Pernambuco state (Brazil). Samples were taken between June 2011 and August 2012. The sampling of cladocerans and environmental variables was performed at four fixed points, using a plankton net $(45 \mu \mathrm{m})$ and a multiparameter probe. Twenty-two cladoceran species were recorded, with two new occurrences for Pernambuco state: Chydorus cf. brevilabris and Macrothrix superaculeata. The species richness of non-planktonic cladocerans (16) was higher than that of planktonic ones (4). The mean density was $186.7 \pm 273.6$ ind. $\mathrm{L}^{-1}$. Macrothrix elegans, Diaphanosoma spinulosum and Ephemeroporus hybridus were the most abundant. The fluctuation index of the main species showed greater instability during the driest months or greater rainfall, a pattern not observed for the environmental data. However, the pond did not show limnological and cladoceran structure differences between the dry and rainy seasons and between the areas with and without macrophytes. With the exception of temperature and rainfall, the structure and richness of cladocerans was not related to the fluctuation of the other variables. Warmer months had higher densities and richness of cladocerans. On the other hand, months of greatest rainfall had lower richness, especially for the Chydoridae family. Although this Caatinga pond is maintained exclusively by rainwater, the richness of cladocerans is high when compared to other tropical and subtropical ecosystems. These results suggest that rainfall and temperature exert greater control on the dynamics of cladocerans in the Caatinga's temporary shallow ponds, and demonstrate the importance of these ecosystems to biodiversity in the semiarid region.
\end{abstract}

Key words: Cladocerans, fluctuation, macrophytes, Northeastern Brazil, Semiarid 


\section{INTRODUCTION}

Despite being within the Brazilian semiarid region, the Caatinga has thousands of small aquatic ecosystems spread across it (Maltchik, 2000). Some of these environments are formed naturally by rainfall and geomorphological characteristics of the area where they are found (Maltchik, 2000; Melo Júnior et al., in press), most of them being totally unknown in terms of biodiversity of invertebrates. Consequently, the lack of extensive studies on the ecological processes underlying the Caatinga biome and its waterways, and the lack of knowledge about its biodiversity have led, until recently, to the erroneous perception that the aquatic biota is poor in species and endemism (see review by Maltchik and Medeiros, 2006).

Given the hydric irregularity characterizing the Brazilian semiarid region, temporary lagoons or ponds represent ecosystems of major importance, since they consist of natural environments that accumulate water during the rainy season, which may reduce its volume or even dry it during drought (Silva et al., 2008), although in rainy season the rainfalls can be not sufficient to keep the lentic ecosystems flooded during a long period. These water bodies are widely distributed around the world and particularly in the northeast region of Brazil they play a role of great importance from the point of view of evolution, ecology and exploitation of wild fauna and flora (Maltchik, 2000; Tundisi and Matsumura-Tundisi, 2008), even sustaining high productivity and biodiversity (Cardoso et al., 2012). However, the processes maintaining the species diversity at local and regional levels are still poorly understood, especially in tropical aquatic systems (Aranguren-Riaño et al., 2011).

The cladocerans are consumers, like other zooplankton organisms, located at the base of the trophic webs of natural aquatic ecosystems with an important role in energy transfer synthesized by primary producers for other links in the food web and also in nutrient cycling (Meláo et al., 2005). These organisms have strategies that ensure the maintenance of diversity in the face of changes in the water volume of temporary ponds, contributing to the support of these important natural resources. This persistence of aquatic fauna is the result of complex interaction between biotic and abiotic features, which are still poorly known in tropical regions (Almeida et al., 2012).

A greater diversity of cladocerans can be found in the littoral region of continental water bodies, areas of transition between aquatic and terrestrial environments (Castilho-Noll et al., 2010), especially those occupied by aquatic macrophytes. Although the littoral areas have rich biodiversity, according to Nogueira et al. (2003), the biology and ecology of cladocerans in these areas are still poorly known, particularly when compared to organisms living in open waters (Maia-Barbosa et al., 2008).

The large number of temporary aquatic environments in the Caatinga region, coupled with the high potential of these ecosystems to store rich biodiversity that is still unknown by science, means that expansion of knowledge about its biota is imminent. According to Crispin and Freitas (2005), studies on these ecosystems are important for understanding and protecting these unique and variable habitats. Thus, the present study aimed to describe the composition and diversity of cladocerans in a temporary shallow pond of the Mata da Pimenteira State Park, an area with a history of more than 20 years of conservation in the Caatinga of Pernambuco.

\section{Material And Methods \\ Study Area}

The temporary shallow pond of the Mata da Pimenteira State Park (753'48.96"S / $\left.38^{\circ} 18^{\prime} 14.30^{\prime \prime} \mathrm{W}\right)$ is located in Serra Talhada, in the semiarid region of Pernambuco state (Fig. 1), about $420 \mathrm{~km}$ from the capital Recife. It covers approximately 890 ha and for the most part corresponds to the tops of mountains and fragments of arboreal Caatinga. This area has a large complex of hills and rocky outcrops, providing a strikingly beautiful landscape. It consists of a stretch of Caatinga with historic 


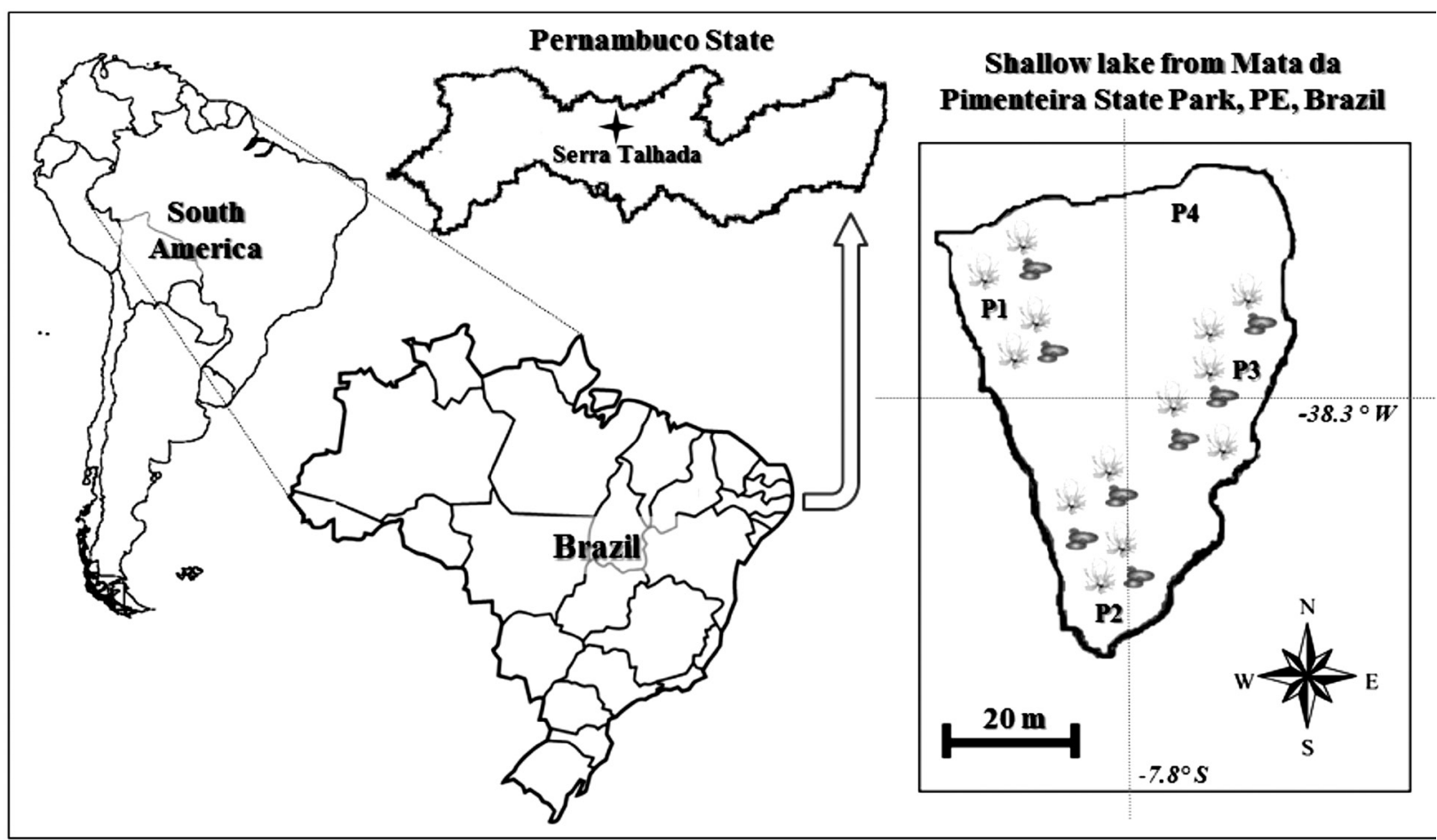

Figure 1. Location of a temporary shallow pond in the Mata da Pimenteira State Park (Serra Talhada, Caatinga of Pernambuco), with the distribution scheme of the sampling points with the presence (P1, P2 and P3) and without vegetation (P4).

conservation of at least 20 years, which was officially categorized as a State Park-type Conservation Unit in January 2012.

The landscape of the Mata da Pimenteira State Park presents a rich diversity of vegetation, in addition to other temporary shallow lagoons and creeks. The studied pond consists of a small and shallow water body, with depth not exceeding two meters (the depth showed a continuous decline during the study, reducing to about 0,1 meters in the last month of sampling), having a flooded area of approximately $2,900 \mathrm{~m}^{2}$ with its native riparian vegetation preserved. Moreover, it presents a wide variety of aquatic macrophytes, including floating and fixed submerged, amphibious and emerging ones, such as: Nymphaea pulchella D.C., Chara martiana Wallman, Echinodorus palaefolius (Nees \& Mart.) J.F. Macbr., Croton argeuteus L., Tarenaya spinosa (Jacq.) Raf. and Eclipta prostrata (L.) L. (Cordeiro et al., in press). The seasons in the semiarid region are variable between the years (Crispin et al., 2006), but generally the rainy season is registered between December and April, while the dry season is observed during May to November.

\section{Limnological variables}

The monthly mean values for rainfall in the region of the Mata da Pimenteira State Park were obtained from the website of the Agronomic Institute of Pernambuco (IPA). Data on the limnological variables of the studied pond (water temperature, $\mathrm{pH}$, dissolved oxygen, conductivity, total solids, turbidity and salinity) were measured from a multiparameter probe, Horiba U-52 model. The measurements of these variables were started in October 2011.

\section{Procedures for sampling and analysis of biological material}

The cladoceran samples were taken in the dry (June, July and October 2011, and May and August 2012) and in the rainy (December 2011, and January and March 2012) seasons, in four fixed sampling points in the littoral area of the pond, three with and one without the presence of macrophytes. Due to logistical problems, the sampling in June 2011 was only qualitative. A lot of macrophytes in almost any littoral region of the lake enabled the collection of planktonic fauna at a single sampling point. At each point, approximately 
$100 \mathrm{~L}$ of water at the subsurface were sampled, with the aid of a graduated container, filtered in plankton net with $45 \mu \mathrm{m}$ mesh size and fixed with $4 \%$ neutral formalin (Harris et al., 2000). However, this method apparently only allows sampling of cladocerans inhabiting the water between the macrophytes, making unfeasible the sampling of some individuals that were adhered to plants. Considering this fact, the number of individuals of the truly phytophilous species is, therefore, likely to be underestimated.

In the laboratory, the organisms were observed under optical microscope and stereomicroscope with identification performed from the usual dissection methods for microcrustaceans and specialized bibliography (Smirnov, 1996; Elmoor-Loureiro, 1997). For each sample, the quantification was carried out through three 2-mL replicates into SedgwickRafter-type chambers, prepared specifically for this volume, in concentrated samples at $50 \mathrm{~mL}$ (May 2012) to $300 \mathrm{~mL}$ (August 2012). The samples with a low number of organisms were counted in full.

Data were initially treated regarding the species richness, relative abundance $(\%)$, frequency of occurrence (\%), density of individuals (ind. $\mathrm{L}^{-1}$ ), diversity index of Shannon-Wiener ( $\left.\mathrm{H}^{\prime}\right)$ based on the $\log _{2}$ (Shannon, 1948) and the evenness calculated according to Pielou (1977). Furthermore, fluctuation index (Guisande-González et al., 2006) was applied, using data on number density for the most common and abundant species, and data of environmental variables were also used for obtaining the index of environmental fluctuation, using the equation:

$$
D=\sum_{i=1}^{s} p_{i} \log _{2} \frac{p_{i}}{p_{i m}}
$$

where $s$ is the number of variables, $P i$ is the relative proportion of the variable $i$ at specific time and Pim is the reference state, which is calculated as the average figure for the relative proportions of the variable $i$ during the study period. Thus, comparing the two indexes is possible to observe in which period the environmental variables were most associated with the cladocerans' dynamic. The differences in all biological and environmental variables between the littoral areas with and without macrophytes, and between the seasons (dry and rainy) were assessed using the non-parametric Mann-Whitney test (U). The Pearson correlation matrix was used in order to highlight the possible relationships among environmental variables (water temperature, $\mathrm{pH}$, dissolved oxygen, oxygen saturation, conductivity, total solids, turbidity and salinity, and their fluctuation index). The outliers were analyzed in this last case. On the other hand, the Spearman correlation test was also used in order to emphasize the possible relationships among biological (richness, density, fluctuation index for the major species, diversity and evenness) and the environmental variables. Variables that showed significant correlations $(\mathrm{p}<0.05)$ were selected to explain the community structure of cladocerans. For statistical analyses, the statistical package Bioestat 5.3 was used.

\section{RESULTS}

\section{Limnological variables}

During the whole study, the historical rainy season in the region showed greater precipitation than the dry season (MannWhitney; p < 0.05). In July 2011, and May and August 2012, the period was dry $(<15$ mm; Fig. 2A); in January and March 2012 the period was rainy, but the rainfalls $(<50$ $\mathrm{mm}$ ) were not sufficient to permit that a large quantity of water remained in the pond. As a consequence of this, the water depth decreased during whole period (Fig. 2B). In July 2011 the pond was almost completely flooded, even in the dry season. However, the pond did not show limnological differences between the dry and rainy seasons (Mann-Whitney; p > 0.05). Also, no significant differences in these variables were detected between the sampling areas, with and without macrophytes (MannWhitney; $\mathrm{p}>0.05$ ).

The water temperature was always high, especially in the rainy season, being higher for data measured among macrophytes. The 


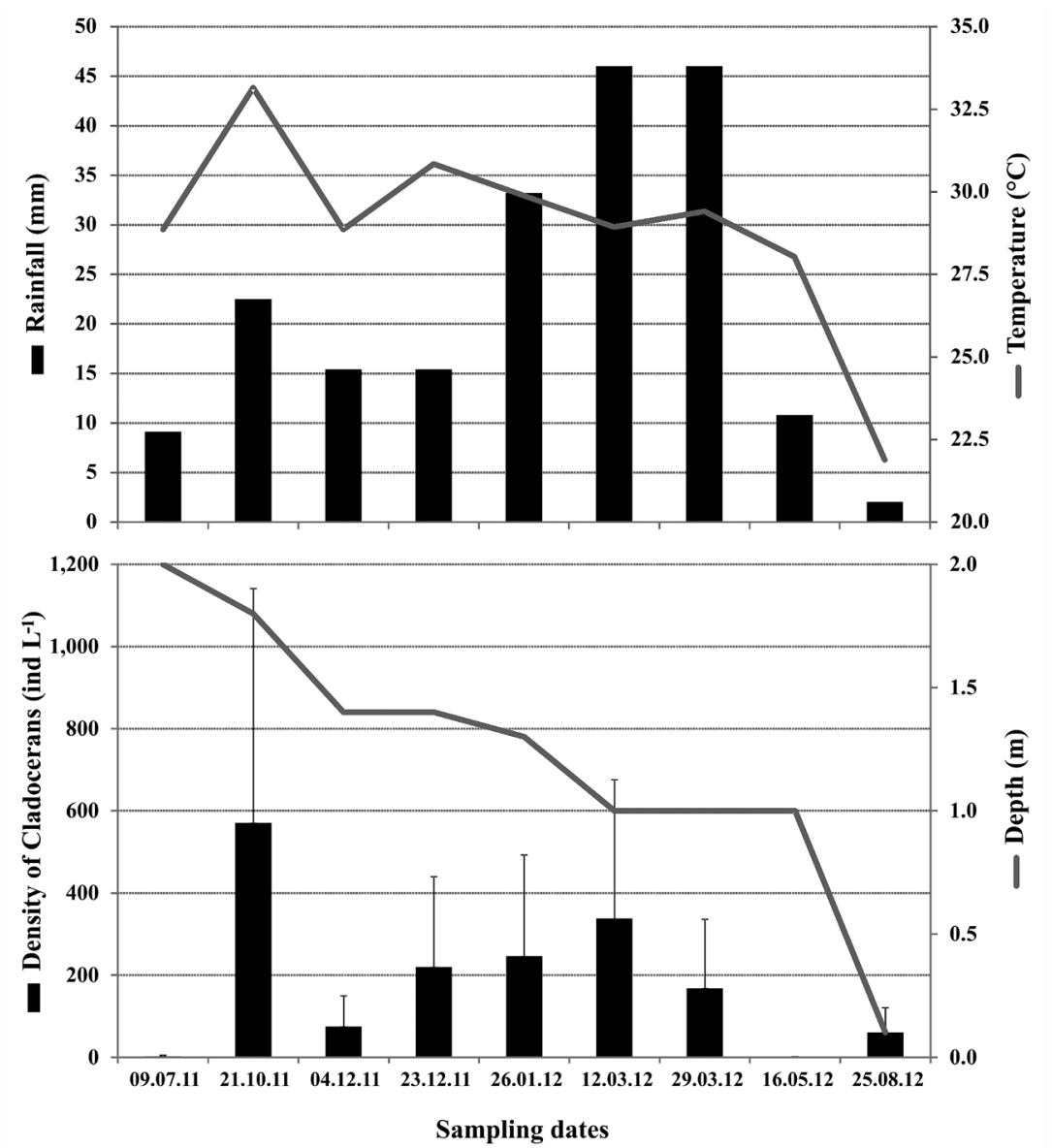

Figure 2. Monthly variation of the (A) mean water temperature $\left({ }^{\circ} \mathrm{C}\right)$ and rainfall $(\mathrm{mm})$, and $(\mathrm{B})$ density (mean \pm standard deviation; ind. $\mathrm{L}^{-1}$ ) of cladocerans and water depth of a shallow temporary pond in the Mata da Pimenteira State Park (Caatinga of Pernambuco). Sampling dates format: dd.mm.yy.

only exception was observed during the dry season in August $2012\left(20.9^{\circ} \mathrm{C}\right.$ ) (Fig. 2A). The water was predominantly well oxygenated (4.1 to $13.9 \mathrm{mg} \mathrm{L}^{-1}$ ), with a $\mathrm{pH}$ from slightly acidic to alkaline (5.3 to 9.6) and low electrical conductivity $\left(0.2-0.5 \mathrm{mS} \mathrm{cm} \mathrm{cm}^{-1}\right)$. Regarding the other limnological variables, oxygen saturation was higher in January 2012 (rainy season) for both collection points with vegetation (184\%) and without vegetation points (168\%). The highest values for turbidity and salinity were also recorded in January 2012 (379.67 NTU and 0.05 , respectively) when the rainfall was above $30 \mathrm{~mm}$ (rainy season), and in August 2012 (958 NTU and 0.02 respectively), and the water stock was low (dry season) and rather trampled by large-size vertebrates (Tab. 1).

Cladoceran community

Twenty-two cladoceran species were recorded, distributed among the families Sididae (2), Moinidae (1), Daphniidae (3), Ilyocryptidae (1), Macrothricidae (2) and
Chydoridae (13), the latter accounting for almost $60 \%$ of total. Among the species identified, two are new records for the state of Pernambuco: Chydorus cf. brevilabris Frey, 1980 and Macrothrix superaculeata (Smirnov, 1992) (Tab. 2).

The values of species richness were slightly higher in almost every month at the sampling points with vegetation, ranging from three to 15 species; the total richness of nonplanktonic cladocerans (16 species) was higher than that of the planktonic ones (four species). Higher values of richness were recorded for the cladoceran community when precipitation was less than $30 \mathrm{~mm}$ in the region (Tables 2, 3 ), with a reduction in the number of taxa when precipitation was greater than $30 \mathrm{~mm}$, especially for members of the Chydoridae family (Table 2).

Only one species was exclusive to the rainy season: Diaphanosoma brevireme Sars, 1900, while seven other species occurred 
Table 1. Amplitude (minimum-maximum), monthly mean and standard deviation (SD) of limnological variables in a temporary shallow pond in the Mata da Pimenteira State Park (Caatinga of Pernambuco), considering the sampling areas with and without vegetation.

\begin{tabular}{l|cccccc}
\hline \multirow{2}{*}{ Variable } & \multicolumn{3}{c}{ With vegetation } & \multicolumn{3}{c}{ Without vegetation } \\
\cline { 2 - 7 } & Amplitude & Mean & SD & Amplitude & Mean & SD \\
\hline Water temperature $\left({ }^{\circ} \mathrm{C}\right)$ & $20.9-35.2$ & 29.3 & 3.4 & $22.4-29.6$ & 27.8 & 2.4 \\
$\mathrm{pH}$ & $5.3-9.6$ & 7.9 & 1.2 & $6.4-8.2$ & 7.2 & 0.6 \\
Conductivity $\left(\mathrm{mS} \mathrm{cm}^{-1}\right)$ & $0.2-0.5$ & 0.3 & 0.1 & $0.2-0.3$ & 0.2 & 0.06 \\
Turbidity (NTU) & $6.1-958$ & 119 & 228 & $9.5-312$ & 67.4 & 120 \\
Dissolved oxygen $\left(\mathrm{mg} \mathrm{L}^{-1}\right)$ & $4.6-13.9$ & 9.3 & 2.9 & $4.1-12.8$ & 8.8 & 3.2 \\
Oxygen saturation $(\%)$ & $61.2-184$ & 122.4 & 41.1 & $52.9-168$ & 113.7 & 41.5 \\
Total solids $\left(\mathrm{g} \mathrm{L}^{-1}\right)$ & $0.09-0.31$ & 0.20 & 0.15 & $0.1-0.18$ & 0.10 & 0.04 \\
Salinity & $0.01-0.02$ & 0.00 & 0.004 & $0.01-0.05$ & 0.00 & 0.01 \\
\hline
\end{tabular}

Table 2. Inventory and distribution of the cladocerans considering their occurrence depending on rainfall and those from areas with and without vegetation in a temporary shallow pond in the Mata da Pimenteira State Park (Caatinga of Pernambuco). F.O.: frequency of occurrence.

\begin{tabular}{|c|c|c|c|c|c|c|}
\hline \multirow[b]{2}{*}{ Species } & \multicolumn{3}{|c|}{ Precipitation } & \multirow[b]{2}{*}{ F.O. (\%) } & \multicolumn{2}{|c|}{ Occurrence } \\
\hline & $<15 \mathrm{~mm}$ & $15.1-30 \mathrm{~mm}$ & $>30 \mathrm{~mm}$ & & $\begin{array}{c}\text { With } \\
\text { vegetation }\end{array}$ & $\begin{array}{c}\text { Without } \\
\text { vegetation }\end{array}$ \\
\hline \multicolumn{7}{|l|}{ SIDIDAE } \\
\hline Diaphanosoma brevireme Sars, 1901 & & & $\mathrm{x}$ & 8.1 & $\mathrm{x}$ & $\mathrm{x}$ \\
\hline Diaphanosoma spinulosum Herbst, 1966 & $\mathrm{x}$ & $\mathrm{x}$ & $\mathrm{x}$ & 59.5 & $\mathrm{x}$ & $\mathrm{x}$ \\
\hline \multicolumn{7}{|l|}{ MOINIDAE } \\
\hline Moina micrura Kurz, 1873 & $\mathrm{x}$ & & $\mathrm{x}$ & 13.5 & $\mathrm{x}$ & $\mathrm{x}$ \\
\hline \multicolumn{7}{|l|}{ DAPHNIIDAE } \\
\hline Ceriodaphnia cornuta Sars, 1885 & $\mathrm{x}$ & $\mathrm{x}$ & $\mathrm{x}$ & 67.6 & $\mathrm{x}$ & $\mathrm{x}$ \\
\hline Simocephalus acutirostris King, 1852 & $\mathrm{x}$ & $\mathrm{x}$ & $\mathrm{x}$ & 35.1 & $\mathrm{x}$ & $\mathrm{x}$ \\
\hline Simocephalus mixtus (Müller, 1776) & $\mathrm{x}$ & $\mathrm{x}$ & $\mathrm{x}$ & 21.5 & $\mathrm{x}$ & $\mathrm{x}$ \\
\hline \multicolumn{7}{|l|}{ ILYOCRYPTIDAE } \\
\hline Ilyocryptus spinifer Herrick, 1881 & $\mathrm{x}$ & $\mathrm{x}$ & $\mathrm{x}$ & 27.0 & $\mathrm{x}$ & $\mathrm{x}$ \\
\hline \multicolumn{7}{|l|}{ MACROTHRICIDAE } \\
\hline Macrothrix elegans Sars, 1900 & $\mathrm{x}$ & $\mathrm{x}$ & $\mathrm{x}$ & 97.3 & $\mathrm{x}$ & $\mathrm{x}$ \\
\hline Macrothrix superaculeata (Smirnov, 1982) & $\mathrm{x}$ & $\mathrm{x}$ & $\mathrm{x}$ & 10.8 & $\mathrm{x}$ & $\mathrm{x}$ \\
\hline \multicolumn{7}{|l|}{ CHYDORIDAE } \\
\hline \multicolumn{7}{|l|}{ CHYDORINAE } \\
\hline Chydorus cf. brevilabris Frey, 1980 & $\mathrm{x}$ & & & 2.7 & $\mathrm{x}$ & \\
\hline Chydorus nitidulus (Sars, 1901) & $\mathrm{x}$ & $\mathrm{x}$ & & 5.4 & $\mathrm{x}$ & \\
\hline Chydorus pubescens Sars, 1900 & $\mathrm{x}$ & & & 16.2 & $\mathrm{x}$ & $\mathrm{x}$ \\
\hline Alona dentifera (Sars, 1901) & & $\mathrm{x}$ & & 2.7 & & $\mathrm{x}$ \\
\hline Ephemeroporus hybridus (Daday, 1905) & $\mathrm{x}$ & $\mathrm{x}$ & & 51.3 & $\mathrm{x}$ & $\mathrm{x}$ \\
\hline Chydorus cf. sphaericus (Müller, 1776) & & $\mathrm{x}$ & & 8.1 & $\mathrm{x}$ & \\
\hline \multicolumn{7}{|l|}{ ALONINAE } \\
\hline Alona glabra Guerne \& Richard, 1892 & & $\mathrm{x}$ & & 8.1 & $\mathrm{x}$ & $\mathrm{x}$ \\
\hline Alona guttata Sars, 1861 & $\mathrm{x}$ & & & 2.7 & $\mathrm{x}$ & \\
\hline Coronatella poppei (Richard, 1896) & $\mathrm{x}$ & $\mathrm{x}$ & & 21.6 & $\mathrm{x}$ & $\mathrm{x}$ \\
\hline Anthalona verrucosa (Sars, 1901) & $\mathrm{x}$ & $\mathrm{x}$ & & 10.8 & $\mathrm{x}$ & $\mathrm{x}$ \\
\hline Karualona muelleri (Richard, 1897) & $\mathrm{x}$ & $\mathrm{x}$ & $\mathrm{x}$ & 29.7 & $\mathrm{x}$ & $\mathrm{x}$ \\
\hline Leydigia ipojucae Brehm, 1938 & & $\mathrm{x}$ & & 5.4 & $\mathrm{x}$ & \\
\hline Oxyurella longicaudis (Birge, 1910) & $\mathrm{x}$ & $\mathrm{x}$ & $\mathrm{x}$ & 29.7 & $\mathrm{x}$ & $\mathrm{x}$ \\
\hline Richness & 17 & 17 & 11 & & 21 & 17 \\
\hline
\end{tabular}


exclusively during the dry season: Chydorus cf. brevilabris, Alona dentifera (Sars, 1901), Alona guttata Sars, 1862, Leydigia ipojucae Brehm, 1938, Alona glabra Guerne \& Richard, 1892, Chydorus nitidulus (Sars, 1901) and Chydorus pubescens Sars, 1900.

Four species had frequency of occurrence exceeding 50\%. The non-planktonic species Macrothrix elegans Sars, 1901 had the highest frequency of occurrence, followed by planktonic species Ceriodaphnia cornuta Sars, 1886 and Diaphanosoma spinulosum Sars, 1901 and the non-planktonic Ephemeroporus bybridus (Daday, 1905). The others had frequencies lower than 36\% (Table 2).

The mean density of cladocerans was $186.7 \pm 273.6$ ind. $\mathrm{L}^{-1}$, with the lowest values recorded in some months of both dry and rainy seasons (Fig. 2b). As a consequence of this, during the whole study, the cladoceran density was not different between the seasons (Mann-Whitney; p > 0.05). However, the two lower values were registered during the dry season. Besides, due to the large variability of density data, no significant differences were detected between the two sampling areas, with and without macrophytes (Mann-Whitney; p $>0.05$ ).

The most abundant species were Macrothrix elegans Sars, 1900, Diaphanosoma spinulosum Herbst, 1966 and Ephemeroporus bybridus (Daday, 1905). Macrothrix elegans occurred in virtually every month and had its highest density in rainy season (January 2012; $227.0 \pm 215.7$ ind. $\mathrm{L}^{-1}$ ), just as Diaphanosoma spinulosum (late March 2012; $148.9 \pm 208.1$ ind. $\left.\mathrm{L}^{-1}\right)$. On the other hand, Ephemeroporus bybridus showed the highest density in dry season (October 2011; $486.0 \pm 601.2$ ind. $\left.\mathrm{L}^{-1}\right)$. To this last species, the peak coincided with the highest values of water temperature $\left(>33^{\circ} \mathrm{C}\right)$, whereas no other species showed a population peak in the month of lower water temperature (August 2012). In a month of the rainy season (early March 2012), the lowest pH (5.9) was recorded, and this time it coincided with the occurrence of population peaks of Ceriodaphnia cornuta Sars, $1886(151.1 \pm 13.3$ ind. $\left.\mathrm{L}^{-1}\right)$, Moina micrura Kurz, $1873(39.5 \pm$ 47.3 ind. $\mathrm{L}^{-1}$ ) and Diaphanosoma brevireme Sars, 1900 (221.1 ind. $\mathrm{L}^{-1}$ ).

Both cladoceran diversity and evenness data were not different between the seasons and between the sampling areas with and without vegetation (Mann-Whitney test, $\mathrm{p}>0.05$ ). The Shannon-Wiener diversity index showed values ranging from very low (between 0 and 1 bit. ind $^{-1}$ ) to medium (between 2 and 3 bits. ind $^{-1}$ ), varying between 0.00 and 2.11 bits. ind $^{-1}$, both for the point without vegetation. Higher values of diversity were recorded for the cladoceran community when precipitation was less than $30 \mathrm{~mm}$ in the region. The lowest values for diversity were recorded in the dry season (May 2012), with only three species: Macrothrix superaculeata (Smirnov, 1992), Diaphanosoma spinulosum Herbst, 1966 and Coronatella poppei (Richard, 1896). In this same month, the evenness recorded their minimum value $(0.00)$ for the area without vegetation. The maximum evenness value was 0.971 (rainy season), registered also for the area without vegetation. Other three values higher than 0.8 were registered during the dry season (Tab. 3).

Cladoceran community, environmental variables and scores of fluctuation index

The density and richness of cladocerans were positively correlated with water temperature (Spearman, $\mathrm{r}=0.50$ and $\mathrm{p}<0.01$ and $\mathrm{r}=0.43$ and $\mathrm{p}<0.05$, respectively). The other parameters of the cladoceran community did not show significant correlation with the any variables (Spearman, $\mathrm{p}>0.05$ ). The density of Macrothrix elegans was correlated with dissolved oxygen (Spearman, $r=0.39$ and $\mathrm{p}<0.05$ ) and Ceriodaphnia cornuta abundance showed a negative correlation with $\mathrm{pH}$ (Spearman, $\mathrm{r}=-0.36$ and $\mathrm{p}<0.05)$.

The fluctuation index for the most frequent and abundant species (Ceriodaphnia cornuta, Diaphanosoma spinulosum, Ilyocryptus spinifer, Karualona muelleri, Simocephalus acutirostris, and Macrothrix elegans) showed no significant correlation with any limnological 
Table 3. Temporal variation in richness, diversity and evenness of cladocerans from areas with and without vegetation in a temporary shallow pond in the Mata da Pimenteira State Park (Caatinga of Pernambuco).

\begin{tabular}{lcccccc}
\hline \multirow{2}{*}{ Month } & \multicolumn{2}{c}{ Richness } & \multicolumn{2}{c}{$\begin{array}{c}\text { Diversity } \\
\left(\mathbf{H}^{\prime} \text {; bits. ind }\right.\end{array}$} \\
& $\begin{array}{c}\text { With } \\
\text { vegetation }\end{array}$ & $\begin{array}{c}\text { Without } \\
\text { vegetation }\end{array}$ & $\begin{array}{c}\text { With } \\
\text { vegetation }\end{array}$ & $\begin{array}{c}\text { Without } \\
\text { vegetation }\end{array}$ & $\begin{array}{c}\text { Evenness }\left(\mathbf{J}^{\prime}\right) \\
\text { With }\end{array}$ & $\begin{array}{c}\text { Without } \\
\text { vegetation }\end{array}$ \\
& 12 & - & 1.963 & - & 0.686 & - \\
June 2011 & 9 & 3 & 1.969 & 1.371 & 0.816 & 0.865 \\
July 2011 & 15 & 10 & 1.238 & 1.874 & 0.427 & 0.564 \\
October 2011 & 6 & 7 & 1.212 & 2.106 & 0.639 & 0.750 \\
Early December 2011 & 6 & 2 & 1.006 & 0.971 & 0.626 & 0.971 \\
Late December 2011 & 9 & 4 & 1.345 & 0.750 & 0.515 & 0.375 \\
January 2012 & 8 & 4 & 1.532 & 1.423 & 0.620 & 0.711 \\
Early March 2012 & 5 & 4 & 1.135 & 0.671 & 0.722 & 0.336 \\
Late March 2012 & 3 & 1 & 0.681 & 0.000 & 0.553 & 0.000 \\
May 2012 & 5 & 5 & 1.543 & 1.581 & 0.854 & 0.681 \\
August 2012 & 5 & & &
\end{tabular}

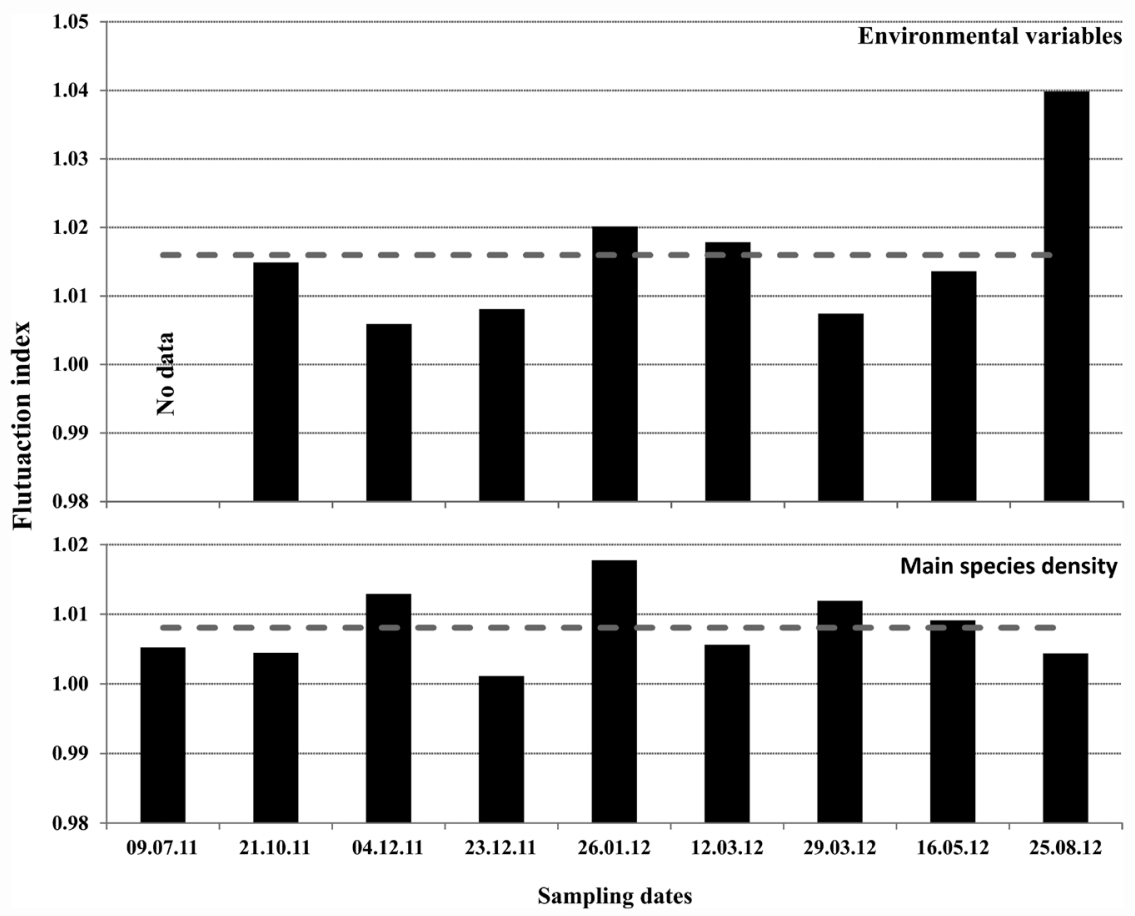

Figure 3. Monthly variation of the fluctuation indexes of environmental variables and the density of the main species (most abundant and frequent species) of cladocerans from a temporary shallow pond in the Mata da Pimenteira State Park (Caatinga of Pernambuco). Sampling dates format: dd.mm.yy.

variable, but varied markedly during the study period, with greater instability during two extreme periods: when drought was most severe in spring (August and early December 2011) or when rainfall was high (late March 2012), being more stable in those months with intermediate rainfall (Fig. 3). However, during the whole study, this fluctuation index was not different between the seasons (MannWhitney; $\mathrm{p}>0.05$ ).
In the same way, the fluctuation index of environmental variables did not show differences between the seasons (MannWhitney; $\mathrm{p}>0.05$ ), not varying much over the study period, except for the months when the pond almost dried out (December 2011 and August 2012) (Fig. 3). However, this index showed a negative correlation with temperature (Pearson, $\mathrm{r}=-0.75$ and $\mathrm{p}<0.05$ ) and a positive correlation with turbidity (Pearson, $\mathrm{r}=0.74$ and $\mathrm{p}<0.05)$. 


\section{DisCussion}

The temporary shallow pond of Mata da Pimenteira State Park showed great variability in the structure of cladoceran populations and major environmental variables. This variability, however, was not associated to the seasons, even the precipitation has showed differences between dry and rainy seasons. According to Maltchik (1990), the lagoons of the semiarid region are characterized by low and irregular rainfall amounts with 1 to 11 months of drought, and this irregularity is observed between the areas and the years in semiarid region (Crispim et al., 2006). This may explain the instability in the fluctuation index of species and environmental variables during the driest months or those with greater precipitation, which ends up promoting significant changes in the environment. According to Vieira et al. (2009), changes in environmental characteristics resulting from irregular rainfall are determining factors in the dynamics of zooplankton communities from semiarid region.

The knowledge of the fauna of limnic cladocerans in Brazil is still limited (ElmoorLoureiro, 2000), so it is important to carry out studies on the diversity of these organisms in the different types of water bodies to increase knowledge of this keycommunity to the dynamics of freshwater ecosystems. Accordingly, this study stands out by representing one of the first monthly surveys on the diversity of planktonic and non-planktonic cladocerans in temporary environments of Caatinga provinces. In a recent update of the list of cladocerans to Pernambuco, the occurrence of 51 taxa was verified (Soares and Elmoor-Loureiro, 2011). Thus, the two new occurrences in Pernambuco (Chydorus cf. brevilabris and Macrothrix superaculeata) increase to 53 the total number of species known in the State.

According to Maltchik (2000), the semiarid lakes are considered true biodiversity hotspots and perhaps therefore the richness of cladocerans in the Pimenteira temporary pond can be considered high when compared with other studies performed in artificial lentic environments (Crispim and Watanabe, 2001; Melo Júnior et al., 2007; Almeida et al., 2009). In the Neotropical region, Aranguren-Riaño et al. (2011) analyzed 15 large lentic ecosystems and recorded a total of 19 cladoceran species, leading the authors to conclude that this richness was related to the large catchment area of the springs. In contrast, 22 species were inventoried for a single shallow and small pond, the object of this study, which sustains a great number of macrophytes when compared with the large lakes studied by Aranguren-Riaño et al. (2011). However, the occurrence of typical planktonic species, such as Ceriodaphnia cornuta and Diaphanosoma brevireme, in the littoral zone of the Pimenteira pond, confirming the plasticity of these species in living areas with and without vegetation, as stated by Elmoor-Loureiro (2007a), show that bio- and ecological features of these species need to be more explored in future studies.

The high richness observed in Mata da Pimenteira pond is also highlighted in comparison with the results observed in other temporary ponds. Crispim and Freitas (2005) recorded ten cladoceran species in a temporary pond in a semi-arid region of Paraíba state (Northeastern Brazil). In a temporary pond in La Pampa province, Argentina, Vignatti et al. (2012) reported 16 zooplankton taxa, but only three of them were cladoceran species. Only five cladoceran species was observed in a temporary pond in Northeastern Spain (Boix et al., 2001). Waterkeyn et al. (2008), studying 30 temporary ponds in Southern France, recorded 17 cladoceran species, the majority belonging to the Chydoridae family.

The dominance of the Chydoridae family was also reported by other researchers (Elmoor-Loureiro, 2007b; Elmoor-Loureiro and Mendonça-Galvão, 2008; Maia-Barbosa et al., 2008; Sousa and Elmoor-Loureiro, 2008; Castilho-Noll et al., 2010; Soares and Elmoor-Loureiro, 2011) (Table 4). This fact may be related to the peculiar characteristics of organisms in this family that have a thicker shell, spines and appendages specialized in grasping substrates, allowing greater mobility and success in the littoral lake areas. Even with 
Table 4. List of some water bodies in the Caatinga, Atlantic Forest, Cerrado and Amazon regions, already studied regarding the cladocerans with highest representativeness of the families Chydoridae and/or Bosminidae $\left(^{*}\right)$. Coordinates: Geographic coordinates; States of Pernambuco (PE), Ceará (CE), Minas Gerais (MG), Goiás (GO) and Amazonas (AM).

\begin{tabular}{|c|c|c|c|c|}
\hline Location/State & Coordinates & $\begin{array}{c}\text { Mesh } \\
(\mu \mathrm{m})\end{array}$ & Richness & Authority \\
\hline Apipucos Dam - PE & $\begin{array}{l}8^{\circ} 1{ }^{\prime} 16.6^{\prime \prime} \mathrm{S} \\
34^{\circ} 55^{\prime} 59^{\prime \prime} \mathrm{W}\end{array}$ & $80 / 100$ & 15 & Soares and Elmoor-Loureiro, 2011 \\
\hline Dois Irmãos Dam - PE & $\begin{array}{c}8^{\circ} 00^{\prime} 51^{\prime \prime} \mathrm{S} \\
34^{\circ} 56^{\prime} 47.7^{\prime \prime} \mathrm{W}\end{array}$ & $80 / 100$ & 18 & Soares and Elmoor-Loureiro, 2011 \\
\hline Tank in the Casa Forte Square - PE & $\begin{array}{l}8^{\circ} 2^{\prime} 4.3 " \mathrm{~S} \\
34^{\circ} 55^{\prime} 10.6^{\prime \prime} \mathrm{W}\end{array}$ & $80 / 100$ & 2 & Soares and Elmoor-Loureiro, 2011 \\
\hline Tanks of the Oceanography Laboratory- UFPE - PE & $\begin{array}{l}8^{\circ} 9^{\prime} \mathrm{S} \\
34^{\circ} 54^{\prime} \mathrm{W}\end{array}$ & $80 / 100$ & 3 & Soares and Elmoor -Loureiro, 2011 \\
\hline Piedade beach flooded - PE & $\begin{array}{c}8^{\circ} 9^{\prime} \mathrm{S} ; \\
34^{\circ} 54^{\prime} \mathrm{W}\end{array}$ & $80 / 100$ & 4 & Soares and Elmoor-Loureiro, 2011 \\
\hline Lagoon of Sítio do Pica-pau Amarelo Club - PE & $\begin{array}{l}7^{\circ} 56^{\prime} \mathrm{S} ; \\
34^{\circ} 52^{\prime} \mathrm{W}\end{array}$ & $80 / 100$ & 3 & Soares and Elmoor-Loureiro, 2011 \\
\hline Engenho Camaçari Lagoon - PE & $\begin{array}{l}8^{\circ} 19^{\prime} \mathrm{S} \\
35^{\circ} 14^{\prime} \mathrm{W}\end{array}$ & $80 / 100$ & 7 & Soares and Elmoor-Loureiro, 2011 \\
\hline $\begin{array}{l}\text { Shallow temporary pond in the State Park Mata da } \\
\text { Pimenteira -PE }\end{array}$ & $\begin{array}{l}7^{\circ} 53^{\prime} 48.96^{\prime \prime} \mathrm{S} \\
38^{\circ} 18^{\prime} 14.30^{\prime \prime} \mathrm{W}\end{array}$ & 45 & 22 & Present study \\
\hline Capivaras Lagoon - GO & $\begin{array}{l}18^{\circ} 16.24 ’ \mathrm{~S} \\
52^{\circ} 50.52^{\prime} \mathrm{W}\end{array}$ & 80 & 12 & Sousa and Elmoor-Loureiro, 2008 \\
\hline Vereda - GO & $\begin{array}{l}18^{\circ} 16^{\prime} 10.9^{\prime \prime} \mathrm{S} \\
52^{\circ} 45^{\prime} 17.9^{\prime \prime} \mathrm{W}\end{array}$ & 80 & 11 & Sousa and Elmoor-Loureiro, 2008 \\
\hline Formoso river - GO & $\begin{array}{l}18^{\circ} 15^{\prime} 42.9^{\prime \prime} \mathrm{S} \\
52^{\circ} 53^{\prime} 23.2^{\prime \prime} \mathrm{W}\end{array}$ & 80 & 4 & Sousa and Elmoor-Loureiro, 2008 \\
\hline Buriti Torto Stream - GO & $\begin{array}{l}18^{\circ} 14.27^{\prime} \mathrm{S} ; \\
52^{\circ} 53.10^{\prime} \mathrm{W}\end{array}$ & 80 & 6 & Sousa and Elmoor-Loureiro, 2008 \\
\hline High Headland of Formoso River - GO & $\begin{array}{l}18^{\circ} 15.59^{\prime} \mathrm{S} ; \\
53^{\circ} 01.96^{\prime} \mathrm{W}\end{array}$ & 80 & 6 & Sousa and Elmoor-Loureiro, 2008 \\
\hline Dom Helvécio lake - MG & $\begin{array}{l}19^{\circ} 45^{\prime} \mathrm{S} \\
42^{\circ} 35^{\prime} \mathrm{W}\end{array}$ & 68 & 32 & Maia-Barbosa et al., 2008 \\
\hline Tupé Lake (large) - AM* & $\begin{array}{l}03^{\circ} 02^{\prime} 35.4 ” S \\
60^{\circ} 15^{\prime} 17.5^{\prime \prime} \mathrm{W}\end{array}$ & 55 & 19 & Ghidini and Santos-Silva, 2011 \\
\hline Precabura Lagoon - CE & $\begin{array}{l}3^{\circ} 48^{\prime} 39^{\prime \prime} \mathrm{S} \\
38^{\circ} 26^{\prime} 41^{\prime \prime} \mathrm{W}\end{array}$ & 80 & 1 & Sousa and Elmoor-Loureiro, 2009 \\
\hline Banana Lagoon - CE & $\begin{array}{l}3^{\circ} 37^{\prime} 28^{\prime \prime} \mathrm{S} \\
38^{\circ} 45^{\prime} 22^{\prime \prime} \mathrm{W}\end{array}$ & 80 & 5 & Sousa and Elmoor-Loureiro, 2009 \\
\hline Marginal pond to Banana Lagoon - CE & $\begin{array}{l}3^{\circ} 37^{\prime} 28^{\prime \prime} \mathrm{S} \\
38^{\circ} 45^{\prime} 22^{\prime \prime} \mathrm{W}\end{array}$ & 80 & 13 & Sousa and Elmoor-Loureiro, 2009 \\
\hline Cahuípe Stream - CE & $\begin{array}{l}3^{\circ} 39^{\prime} 37^{\prime \prime} \mathrm{S} \\
38^{\circ} 48^{\prime} 14^{\prime \prime W}\end{array}$ & 80 & 13 & Sousa and Elmoor-Loureiro, 2009 \\
\hline Lagamar do Cahuípe - CE & $\begin{array}{c}3^{\circ} 36^{\prime} 17^{\prime \prime} \mathrm{S} ; \\
38^{\circ} 46^{\prime} 50^{\prime \prime} \mathrm{W}\end{array}$ & 80 & 10 & Sousa and Elmoor-Loureiro, 2009 \\
\hline Guaribas Stream - CE & $\begin{array}{l}3^{\circ} 33^{\prime} 19^{\prime \prime} \mathrm{S} \\
38^{\circ} 52^{\prime} 27^{\prime \prime} \mathrm{W}\end{array}$ & 80 & 10 & Sousa and Elmoor-Loureiro, 2009 \\
\hline Lagoon at Pecém - CE & $\begin{array}{l}3^{\circ} 33^{\prime} 22^{\prime \prime} \mathrm{S} \\
38^{\circ} 49^{\prime} 26^{\prime \prime} \mathrm{W}\end{array}$ & 80 & 2 & Sousa and Elmoor-Loureiro, 2009 \\
\hline Swamp at Ypioca Farm - CE & $\begin{array}{l}3^{\circ} 34^{\prime} 39^{\prime \prime} \mathrm{S} \\
38^{\circ} 52^{\prime} 31^{\prime \prime} \mathrm{W}\end{array}$ & 80 & 10 & Sousa and Elmoor-Loureiro, 2009 \\
\hline
\end{tabular}

differing climatic conditions, the proximity regarding richness and dominance of the same family may indicate a possible similarity between these ecosystems listed in Table $4-$ most of them being shallow and rich in macrophyte banks. A contrasting and large lake in the Amazon region (Ghidini and SantosSilva, 2011), on the other hand, was the furthest from this pattern because there was dominance of Bosminidae, a typical planktonic family, in terms of number of species - in this case, the great amount of limnetic area in this ecosystem explain this dominance. Furthermore, the net mesh size used in sampling seems to affect the number of species. The number of species was considerably higher when smaller mesh size 
was used, as seen in Mata da Pimenteira pond (Caatinga region), Tupé lake (Amazon region) and Dom Helvécio lake (Mata Atlântica region) (Table 4). However, species richness values are known to be very sensitive to sampling effort and this fact should be considered. Besides the more reduced net mesh size, those three studies had higher sampling efforts when compared to the other studies.

On the other hand, the representatives of the Chydoridae family virtually disappeared in the months of highest rainfall $(>30 \mathrm{~mm})$, especially when considering the subfamily Chydorinae. A reduction in the number of taxa in the subfamily Aloninae was also recorded, with only the non-planktonic species Karualona muelleri and Oxyurella longicaudis being recorded. These months coincided with noticeable reductions in macrophyte banks, with prevalence only of aggregates of the algae Chara martiana Wallman. Whereas rainfall is scarce in semiarid regions, its sporadic occurrence in greater volume (> 30 $\mathrm{mm}$ ) in the Caatinga could act on reducing the macrophyte banks, as already observed for other temporary ponds in the Caatinga (Pedro et al., 2006). According to these authors, the richness of aquatic macrophyte communities is lower in temporary ponds during flood events, and this fact could explain the reduction in Chydoridae species in the Mata da Pimenteira pond, a typically dominant family in terms of species richness in several Brazilian shallow ponds with predominance of macrophytes (Table 4). Moreover, taking into account the visual predominance of Chara martiana in Mata da Pimenteira pond, and considering that cladoceran composition varies with macrophyte size (Lauridsen et al., 1996), the slender folioles of this alga would not be sufficient to maintain Chydoridae populations during the periods when the pond is flooded.

On the other hand, reduced water volume causes instability of aquatic populations and influences diversity of Cladocera (Panarelli et al., 2010). This may be in agreement with the theory proposed by Naselli-Flores et al. (2003), who suggest a tendency of non- equilibrium of the steady-state conditions in the phytoplanktonic community when one or more environmental factors are at the extreme of the range in which organisms can grow and when the change is either too abrupt or too complete and exceeds the homeostatic plateau of the assemblage. Thus, the variation in water volume was accompanied by significant fluctuation in abundance of macrophytes (Cordeiro et al., in press) in the pond studied, which may have promoted changes in composition and structure of populations of cladocerans (mainly the phytophilous ones), probably by interfering with their stability.

In fact, the hydroregime, namely the duration, frequency and predictability of the aquatic phase, is a key feature of temporary habitats in structuring the aquatic community (Vanschoenwinkel et al., 2009). However, the water temperature probably also had an influence on cladocerans. This was the only variable that correlated significantly with the richness and density of these microcrustaceans. A similar result was also observed by Shurin et al. (2010), studying 53 lakes in the temperate zones of North America and Europe, where they found that the chemical variations in ponds tend to exclude zooplankton species, while temperature variability promotes greater richness. Despite being within the semiarid region, the shallow pond of Mata da Pimenteira showed a marked variation in water temperature $\left(20.9\right.$ to $\left.35.2^{\circ} \mathrm{C}\right)$.

Even without showing significant differences regarding the sampling points, diversity data should be discussed because it was expected that the greatest diversity would be recorded at sampling points in the presence of vegetation. According to Sakuma et al. (2002), vegetation areas in the littoral region of lakes have rich biodiversity. This is because aquatic macrophytes provide a habitat and refuge for many organisms in addition to providing greater environmental heterogeneity (Nogueira et al., 2003). However, the maximum diversity was observed at the sampling point without vegetation in early December 2011, with the caveat that most 
species recorded that day were not typical of the plankton. Almeida et al. (2006), studying rotifers in Tapacurá reservoir (Pernambuco), also found significant participation of nonplanktonic taxa in the vegetation-free zone, and the authors related this fact to wind action (which brings up individuals from the bottom), precipitation (which carries various organisms from the margin) and floating macrophytes (moved by wind action and may influence biological communities across the surface of the water column, being an efficient mean of transportation for organisms related to them).

Among all these factors, the wind could be a possible explanation to the greater diversity found for the collection point without vegetation, since the Mata da Pimenteira pond showed no occurrence of floating macrophytes (Cordeiro et al., in press) and/or heavy rainfall in the region for some days prior to the samplings. Moreover, predation of cladocerans may also have been an important factor. For that same pond, França and Severi (in press) reported five fish species [Characidium fasciatum Reinhardt, 1866; Astyanax lacustris (Lütken, 1875); Serrapinnus heterodon (Eigenmann, 1915); Serrapinnus piaba (Lütken, 1875) and Hoplias malabaricus (Bloch, 1794)], which especially in the juvenile stage inhabit the macrophyte banks, feeding on microcrustaceans (Agostinho et al., 2003). However, these two factors (wind and predators) need to be tested in the future to confirm these hypotheses.

The results indicate that although the ecosystem studied here displays intense variations in temperature, water depth and rainfall during the annual cycle and is fed only on rainwater, this temporary shallow pond in the Caatinga houses a rich biodiversity of cladocerans, mainly the non-planktonic ones, and high seasonal variation in the density and structure of their populations, which reinforces the importance of their preservation. The causes and trophic consequences occasioned by reducing the number of taxa of Chydoridae in periods of high rainfall in the Caatinga should be further investigated experimentally.
ACKNOWLEDGMENTS - We would like to thank Nelson Javier Aranguren Riaño (Universidad Pedagógica y Tecnológica de Colombia) for his important suggestions and reference on fluctuation index. We gratefully acknowledge the important suggestions and comments by two anonymous reviewers. We are also in debt to the Academic Unit of Serra Talhada (UAST/UFRPE), for the logistical support in this work, the Programa de Educação Tutorial - PET/MEC/ $\mathrm{SESu} / \mathrm{SECAD}$, for financial support to the first author and the Fundação de Amparo à Ciência e Tecnologia do Estado de Pernambuco - FACEPE (APQ 0664-2.05/10), for financial support for the project. This is contribution number 028 from the LEPLANC.

\section{REFERENCES}

Agostinho, A.A.; Gomes, L.C. and Júlio, H.F. 2003. Relaçóes entre macrófitas aquáticas e fauna de peixes. p. 261- 279. In: S.M. Thomaz and L.M. Bini (eds), Ecologia e manejo de macrófitas aquáticas. Maringá, EDUEM, 341p.

Almeida, V.L.S.; Dantas, Ê.W.; Melo Júnior, M. de.; Bittencourt-Oliveira, M.C. and Moura, A.N. 2009. Zooplanktonic community of six reservoirs in northeast Brazil. Brazilian Journal of Biology, 69(1): 57-65.

Almeida, V.L.S.; Larrazábal, M.E.L.; Moura, A.N. and Melo Júnior, M. 2006. Rotifera das zonas limnética e litorânea do reservatório de Tapacurá, Pernambuco, Brasil. Iheringia, Série Zoologia, 96(4): 445-451.

Almeida, V.L.S.; Larrazábal, M.E.L.; Moura, A.N. and Melo Júnior, M. 2012. Zooplâncton do reservatório de Tapacurá (PE, Brasil): influência do habitat e do estado trófico sobre a biodiversidade. p. 99-127. In: G.J.B Moura; S.M. Azevedo Junior and A.C.A. El-Deir (eds), A biodiversidade da estação ecológica do Tapacurá: uma proposta de manejo e conservação. Recife, NUPEEA.

Aranguren-Riaño, N.; Guisande, C. and Ospina, R. 2011. Factors controlling crustacean zooplankton species richness in Neotropical lakes. Journal of Plankton Research, 33(8): 1295-1303.

Boix, D.; Sala, J. and Moreno-Amich, R. 2001. The faunal composition of Espolla Pond (NE Iberian Peninsula): The neglected biodiversity of temporary waters. Wetlands, 21(4): 577-592.

Bonecker, C.C.; Azevedo, F. and Simôes, N.R. 2011. Zooplankton body-size structure and biomass in tropical floodplain lakes: relationship with planktivorous fishes. Acta Limnologica Brasiliensia, 23(3): 217-228.

Cardoso, M.M.L.; Souza, J.E.R.T.; Crispim, M.C. and Siqueira, R. 2012. Diversidade de peixes de um rio intermitente do semiárido paraibano, Brasil. Biotemas, 25(3): 161-171.

Castilho-Noll, M.S.M.; Câmara, C.F.; Chicone, M.F. and Shibata, E.H. 2010. Pelagic and littoral cladocerans (Crustacea, Anomopoda and Ctenopoda) from reservoirs of the Northwest of São Paulo State, Brazil. Biota Neotropica, 10(1): 21-30.

Cordeiro, W.P.F.S.; Zickel, C.S.; Matos, S.S.; Melo, R.; Caldas, D.R.M.; Melo Júnior, M.; Gomes, A.P.S. and Melo, A.L. In press. Flora aquática de duas lagoas temporárias do Parque Estadual Mata da Pimenteira. In: E.M. Santos; M. Melo Junior; J.S. Silva-Cavalcanti, G.V.L. Almeida (eds), Parque Estadual Mata da Pimenteira - Riqueza natural e conservação da Caatinga.

Crispim, M.C. and Freitas, G.T. 2005. Seasonal effects on zooplanktonic community in a temporary lagoon of northeast Brazil. Acta Limnologica Brasiliensia, 17(4): 385393. 
Crispim, M.C.; Ribeiro, L.L.; Gomes, S.E.M.; Freitas, G.T.P. and Serpe, F.R. 2006. Comparison of different kind of semi-arid aquatic environments based on zooplankton communities. Revista de Biologia e Ciências da Terra, 6(1): 98-111.

Crispim, M.C and Watanabe, T. 2001. What can dry reservoir sediments in a semi-arid region in Brazil tell us about cladocera? Hydrobiologia, 422: 101-105.

Elmoor-Loureiro, L.M.A. 1997. Manual de identificação de cladóceros límnicos do Brasil. Brasília, Universa. 155 p.

Elmoor-Loureiro, L.M.A. 2000. Brazilian cladocera studies: where do we stand? Nauplius, 8(1): 117-131.

Elmoor-Loureiro, L.M.A. 2007a. Levantamento das espécies de Cladocera (Crustacea, Branchiopoda) associados a macrófitas de alagados e zonas marginais. p. 121-150. In: M. J. Martins-Silva (ed). Inventário da biota aquática com vista a conservaçáo e utilização sustentável do bioma cerrado (Serra e vale do rio Paranã). Brasília, Ministério do Meio Ambiente.

Elmoor-Loureiro, L.M.A. 2007b. Non-planktonic cladocerans (Crustacea, Anomopoda, Ctenopoda) from Paraná River Valley, Goiás, Brazil. Revista Brasileira de Zoologia, 24(2): 344-352.

Elmoor-Loureiro, L.M.A. and Mendonça-Galvão, L. 2008. Fauna associada às macrófitas. p. 273-276. In: F.O. Fonseca (ed), Águas Emendadas. Brasília, Seduma.

França, E.J. and Severi, W. In press. Ictiofauna de poças temporárias do Parque Estadual Mata da Pimenteira. In: E.M. Santos; M. Melo Junior; J.S. Silva-Cavalcanti, G.V.L. Almeida (eds), Parque Estadual Mata da Pimenteira Riqueza natural e conservação da Caatinga.

Ghidini, A.R. and Santos-Silva, E.N. 2011. Composition, species richness and patterns of nycthemeral vertical distribution of planktonic cladocereans in a black water Amazonian lake. Nauplius, 19(2): 109-122.

Guisande-González, C.; Barreiro-Felpeto, A.; ManeiroEstraviz, I.; Riveiro-Alarcón, I.; Vergara-Castaño, A.R. and Vaamonde-Liste, A. 2006. Tratamiento de datos. Ed. Díaz de Santos, Madrid, 356p.

Harris, R.P.; Wiebe, P.H.; Lenz, J.; Skjoldal, H.R. and Huntley, M. 2000. ICES Zooplankton methodology manual, Academic Press, San Diego, 684p.

IPA, 2012. Sessão de índices pluviométricos. Available at http://www.ipa.br/indice_pluv.php\#calendario_indices. Accessed on 10 August 2012.

Lauridsen, T.L; Pedersen, L.J.; Jeppesen, E. and Sondergaard, M. 1996. The importance of macrophyte bed size for cladoceran composition and horizontal migration in a shallow lake. Journal of Plankton Research, 18(12): 22832294.

Maia-Barbosa, P.M.; Peixoto, R.S. and Guimarães, A.S. 2008. Zooplankton in littoral waters of a tropical lake: a revisited biodiversity. Brazilian Journal of Biology, 68(4): 10691078.

Maltchik, L. 1990. Ecologia de rios intermitentes tropicais. p. 77-89. In: M.L.M. Pompêo (ed). Perspectivas da limnologia no Brasil. São Luís, União.

Maltchik, L. 2000. Lagoas temporárias do semiárido. Ciência Hoje, 28(167): 67-70.

Maltchik, L. and Medeiros, E.S. 2006. Conservation importance of semi-arid streams in northeastern Brazil: implications of hydrological disturbance and species diversity. Aquatic Conservation: Marine and Freshwater Ecosystems, 16: 665-677.

Melão, M.G.G.; Rocha O. and Roche, K.F. 2005. Produtividade, biomassa, flutuaçóes populacionais e interaçôes biológicas da comunidade planctônica e suas implicaçóes na transferência de energia na cadeia alimentar de um reservatório raso e oligotrófico. p. 25-80. In: K.F. Roche and O. Rocha (eds), Ecologia Trófica de Peixes com ênfase na planctivoria em ambientes lênticos de água doce no Brasil. São Carlos, Rima.

Melo Júnior, M. de.; Diniz, L.P.; Magalhães, M.F.M.; Brito, M.T.S.; Melo, A.L.; Elmoor-Loureiro, L.M.A. and Almeida, V.L.S. In press. Fauna planctônica e fitófila de uma lagoa temporária rasa do Parque Estadual Mata da Pimenteira. In: E.M. Santos; M. Melo Junior; J.S. Silva-Cavalcanti, G.V.L. Almeida (eds), Parque Estadual Mata da Pimenteira - Riqueza natural e conservação da Caatinga.

Melo Júnior, M. de; Almeida, V.L.S.; Paranaguá, M.N. and Moura, A.N. 2007. Crustáceos planctônicos de um reservatório oligotrófico no nordeste do Brasil. Revista Brasileira de Zoociências, 9(1): 19-30.

Naselli-Flores L.; Padisák J.; Dokulil M.T. and Chorus, I. 2003. Equilibrium/Steady-state concept in phytoplankton ecology. Hydrobiologia, 502: 395-403.

Nogueira, M.G.; George, D.G. and Jorcin, A. 2003. Estudo do zooplâncton em zonas litorâneas lacustres: um enfoque metodológico. p. 83-126. In: R. Henry (ed), Ecótonos nas interfaces dos ecossistemas aquáticos. São Carlos: Rima.

Panarelli, E.A.; Casanova, S.M.C. and Henry, R. 2010. Secondary production and biomass of cladocera in marginal lakes after the recovery of their hydrologic connectivity in a river-reservoir transition zone. Lakes \& Reservoirs: Research and Management, 15(4): 319-334.

Pedro, F; Maltchik, L. and Bianchini Jr, I. 2006. Hydrologic cycle and dynamics of aquatic macrophytes in two intermittent rivers of the semiarid region of Brazil. Brazilian Journal of Biology, 66(2B): 575-585.

Pielou, E.C. 1977. Mathematical Ecology. 2 ed. New York: Wiley. 385p.

Sakuma, M.; Hanazato, T. and Nakazato, R. 2002. Methods for quantitave sampling of epiphytic microinvertebrates in lake vegetation. Limnology, 3:115-119.

Shannon, E.C. 1948. A mathematical theory of communication. Bell System Technical Journal, 27: 379423.

Shurin, J.B.; Winder, M.; Adrian R.; Keller, W.; Matthews, B.; Paterson, M.J.; Pinel-Alloul, B.; Rusaks, J.A. and Yan, N.D. 2010. Environmental stability and lake zooplankton diversity - contrasting effects of chemical and thermal variability. Ecology Letters, 13: 453-463.

Silva, N.R.; Sonoda, S.L. and Ribeiro, S.M.M.S. 2008. Spatial and seasonal variation of microcrustaceans (Cladocera and Copepoda) in intermittent rivers in the Jequiezinho River Hydrographic Basin, in the Neotropical semiarid. Acta Limnologica Brasiliensia, 20(3): 197-204.

Smirnov, N.N. 1996. Cladocera: the Chydoridae and Sayciinae (Chydoridae) of the word. Guides to the identification of microinvertebrates of the continental waters of the world, number 11. Amsterdam, Academic Publishing.

Soares, C.E.A. and Elmoor-Loureiro, L.M.A. 2011. Uma atualização da lista de Cladocera Cladocera (Crustacea, Branchiopoda) do Estado de Pernambuco, Brasil. Biota Neotropica, 11(2): 1-6.

Sousa, F.D.R. and Elmoor-Loureiro, L.M.A. 2008. Cladóceros fitófilos (Crustacea, Branchiopoda) do Parque Nacional das Emas, estado de Goiás. Biota Neotropica, 8(1): 159166. 
Sousa, F.D.R. and Elmoor-Loureiro, L.M.A. 2009. A contribution to the fauna of Cladocera (Branchiopoda) from Ceará state, Brazil. Nauplius, 17(2): 101-105.

Tundisi, J.G. and Matsumura-Tundisi, T. 2008. Limnologia. São Paulo, Oficinas de Textos. 631p.

Vanschoenwinkel, B.; Hulsmans, A.; De Roeck, E.; De Vries, C.; Seaman, M. and Brendonck, L. 2009. Community structure in temporary freshwater pools: disentangling the effects of habitat size and hydroregime. Freshwater Biology, 54: $1487-1500$.

Vieira, A.C.B.; Ribeiro, L.L.; Santos, D.P.N. and Crispim, M.C. 2009. Correlation between the zooplankton community and environmental variables in a reservoir from the northeastern semi-arid. Acta Limnologica Brasiliensia, 21(3): 349-358.

Vignatti, A.; Cabrera, G. and Echaniz, S. 2012. Changes in the zooplankton and limnological variables of a temporary hypo-mesosaline wetland of the central region of Argentina during its drying. Pan-American Journal of Aquatic Sciences, 7(2): 93-106.

Waterkeyn, A.; Grillas, P.; Vanschoenwinkel, B. and Brendonck, L. 2008. Invertebrate community patterns in Mediterranean temporary wetlands along hydroperiod and salinity gradients. Freshwater Biology, 53: 1808-1822. 